\title{
有鉤骨鉤骨折の自然治癒例
}

\author{
尾上 英 俊* 木 村一 雄* 松 永 和 剛* 濱 田 賢 治* \\ 山口史 彦* 中村厚 彦* ファンジョージ*
}

\section{Natural Healing of Fracture of the Hook of Hamate : A Case Report}

\begin{abstract}
Hidetoshi Onoue*, Kazuo Kimura*, Kazutaka Matsunaga*, Kenji Hamada*, Fumihiko Yamaguchi*, Atsuhiko Nakamura*, and Huang George*
\end{abstract}

\begin{abstract}
有鉤骨鉤骨折の自然治㾍例と思われた 1 例を経験したので報告する。症例：19 歳男性 バイク走行中 に左手をついて転倒した。初診時の X 線では異常を認めなかつたため, 外固定は行われなかつた。受傷 後 1 カ月，軽度の疼痛が持続するため CT を行い鈎基部に骨折を認めた．ギプス固定を勧めたが同意が得 られず, 大学生として普通に生活した，受傷後 3 力月の CT で骨の連続性を認め, 受傷後 8 力月の最終調 査時には完全に骨癒合し，全く症状を認めなかった。この症例は挫創のため約 1 力月手を使えなかったこ と，非利き手であったこと，バイクに乗らなかったことが骨瘾合に有利に働いたと考えられた。しかし骨 折に対するギプスや低出力超音波パルスなどの医学的な治療は行っていないにもかかわらず骨癒合が得ら れた.
\end{abstract}

A 19-year-old male smashed his left hand in a motorbike accident. As no significant pathological finding was made in his first X-ray, no fixation was applied. One month later, the patient suffered mild pain in his left hand. Subsequent CT scan was performed which revealed fracture of the hoof of hamate. The patient refused casting or any special treatment. A CT scan of the fracture at 4 months showed evidence of healing, and no symptoms were found at 8 months. As the patient was right-handed, he could not use his left hand and motorbike, which contributed the complete union of this fracture without any special treatment.

Key words : hook of hamate (有鉤骨銁), fracture（骨折）, natural healing（自然治㾍）

\section{は じめに}

新鮮有鉤骨鉤骨折はギプス固定などの保存療法で良 好な結果が得られるといわれているがその報告例は少 ない，今回，外固定を行わず，生活指導だけで骨癒合 が得られた有鉤骨鉤骨折を 1 例経験したので報告する.

症例

【症例】19 歳 男性

現病歴：平成 17 年 11 月, バイク走行中に車と衝突 し左手をついて転倒し受傷, 直後に当院救急外来を受 診した.この時は手掌部に挫創・皮膚剥離を認めたが, X 線で骨に異常を認めなかったため外固定は行われ
なかった，受傷後 1 カ月で創は治瘜したが，手関節部 の運動時痛が持続するため整形外科を受診した.

現症：小指球部の創瘢痕に一致して圧痛と手関節掌 背屈運動での疼痛を認めた.

画像所見：単純 X 線（手根管撮影）では骨傷を認 めず，CT で鈎基部に骨折を認めた（図 1).

治療 : ギプス固定と骨片切除術について十分に説明 し, ギプス固定を勧めたが患者側の同意が得られなかっ た.このため腱断裂などの合併症と偽関節になつた場 合の治療として, 骨片切除術について再度説明を行い, 疼痛が生じる行為をしないこと, 特にバイクに乗らな いことを指導し経過を見ることにした.

経過：骨折の状態は CT で確認することにした．疼

\footnotetext{
* 福岡徳洲会病院整形外科 Department of Orthopaedic Surgery, Fukuoka Tokushukai Medical Center, Fukuoka, Japan
} 


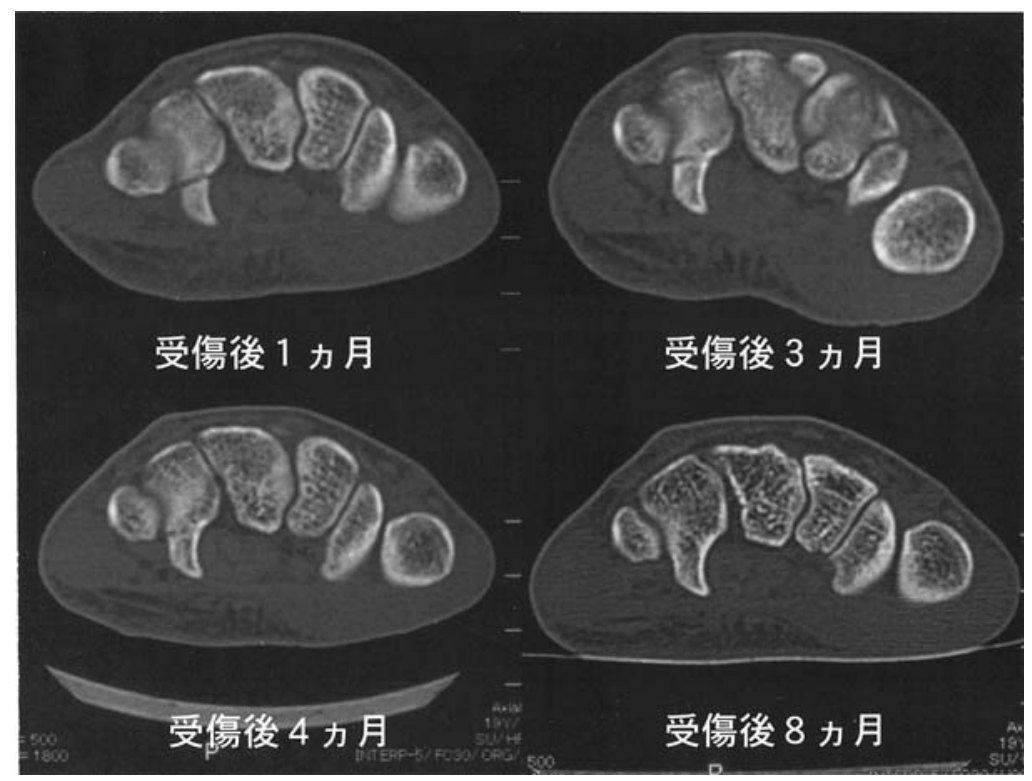

図 119 歳男性 CT で鉤基部の骨折および骨癒合を確認した

痛は受傷後 2 力月頃から徐々に消失していた。受傷後 3 力月，4 力月の CT で骨の連続性を漸次認め，受傷 後 8 カ月の最終診察時には完全に骨癒合し全く症状を 認めなかった(図 1).

$$
\text { 考察 }
$$

有鉤骨鉤骨折は偽関節となつて診断される場合が多 く, 受傷直後に診断がなされることは比較的少ない. 合併症のない偽関節の治療は骨片切除術により安定し た成績が得られており, 新鮮例でも早期にスポーツ復 帰を目指す場合などには骨片切除術が行われてい $3^{1334)}$

保存療法の報告として Whalen らは新鮮骨折 6 例 に対し平均 11 週（6〜12 週）の外固定を行い, 平均 8 週（6〜19 週）で 6 例とも骨癒合が得られたと報告 している . 最近では若年者の陳旧例に対し外固定を 行わず，低出力超音波パルスを照射するだけで癒合が 得られたとの報告も見られる².

今回の症例は挫創のため受傷から約 1 カ月手を使え なかったこと, 患側が食事や書字行為にあまり関係し ない非利き手であったこと，バイクに乗らなかったこ となどが骨癒合に有利に働いたと考えられた.しかし 受傷直後から外固定は行っておらず，診断確定後も低
出力超音波パルスなどの医学的な治療は行わなかつた. また経過観察期間中は大学生としての日常生活をごく 普通に行いながらも骨癒合が得られたことから，この 症例は有鈎骨鉤骨折の自然治癒例といえるのではない かと考えられた。

結語

有鉤骨鉤骨折は早期に診断され適切な治療を行えば, 保存的に骨癒合が得られるといわれている. 今回の症 例はその結果を裏付ける 1 例であった.

$$
\text { 参 考 文 献 }
$$

1) Bishop, A. T., Beckenbaugh, R. D.: Fracture of the hamate hook. J. Hand Surg., 13A (1) : 135-139, 1988.

2）藤岡宏幸ほか：有鈎骨鈎骨折に対する超音波治療と鈎 切除術の比較検討. 日手会誌, $22(2): 54-57,2005$.

3）村上恒二ほか:スポーツにおける有鉤骨鈎骨折の診断と 治療おける問題点. 臨床スポーツ医学, 9 (8)：925-930, 1992.

4）鈴木勝憲ほか:有鉤骨骨折の治療成績について，日手会 誌, 12 (1) : 125-128, 1995.

5) Whalen, J. L., Bishop, A. T., Linscheid, R. L. Nonoperative treatment of acute hamate hook fractures. J. Hand Surg., 17A (3) : 507-511, 1992. 